\title{
Pengaruh Agregat Sungai Battang Terhadap Kekuatan Beton
}

\author{
Dendi Nadaf Mantja *1, Desi Sandy *2, Tjiang A Gunadi *3, \\ ${ }^{* 1}$ Mahasiswa Program Studi Teknik Sipil, Universitas Kristen Indonesia Paulus, Makassar \\ Email dnadafmantja12@gmail.com \\ *2 Dosen Program Studi Teknik Sipil, Universitas Kristen Indonesia Paulus, Makassar, \\ Email Sandy.mylife@tahoo.co.id \\ *3 Dosen Program Studi Teknik Sipil, Universitas Kristen Indonesia Paulus, Makassar, \\ Email Tjiangarifgunadi@gmail.com
}

\begin{abstract}
ABSTRAK
Material alam yang digunakan pada penelitian ini bersumber dari sungai Battang kota Palopo. Tujuan penelitian ini untuk mengetahui karakteristik agregat dan kekuatan beton. Jenis penelitian menggunakan metode American Concrete Institude dengan identifikasi benda uji silinder diameter $15 \mathrm{~cm}$ dan tinggi $30 \mathrm{~cm}$, serta balok dengan panjang $60 \mathrm{~cm}$, lebar $15 \mathrm{~cm}$ dan tebal $15 \mathrm{~cm}$. Pengujian kuat tekan sebanyak 24 benda uji, pengujian kuat tarik belah sebanyak 6 benda uji dan kuat lentur sebanyak 6 benda uji dengan jumlah benda uji keseluruhan sebanyak 36 sampel untuk kuat tekan rencana 23 Mpa dan $30 \mathrm{Mpa}$. Hasil penelitian yang didapatkan dari penelitian ini yaitu untuk uji kuat tekan rencana 23 Mpa dengan nilai sebesar 23,861 Mpa dan kuat tekan rencana 30 Mpa nilai yang didapatkan sebesar 31,501 Mpa, uji kuat tarik belah dengan kuat tekan rencana 23 Mpa dengan nilai yang didapatkan 1,957 Mpa dan kuat tekan rencana 30 Mpa dengan nilai 2,769 Mpa, serta uji kuat lentur kuat tekan rencana 23 Mpa dengan nilai 3,022 Mpa dan untuk kuat tekan rencana $30 \mathrm{Mpa}$ dengan nilai 3,425 Mpa. Kesimpulan dari penelitian ini bahwa karakteristik agregat sungai Battang memenuhi Standar Nasional Indonesia dan dapat mencapai nilai kuat tekan yang direncanakan.
\end{abstract}

Kata Kunci : Agregat Sungai Battang, Uji Kuat Tekan, Uji Kuat Tarik Belah, Uji Kuat Lentur.

\begin{abstract}
The purpose of this study was to determine the aggregate characteristics and concrete strength of the Battang River material. This type of research uses the American Concrete Institute method with the identification of cylindrical specimens with a diameter of $15 \mathrm{~cm}$ and a height of $30 \mathrm{~cm}$, a beam with a length of $60 \mathrm{~cm}$, width of $15 \mathrm{~cm}$, thickness of $15 \mathrm{~cm}$. The results of the research on the plan compressive strength test $23 \mathrm{Mpa}$, amounting to $23.861 \mathrm{Mpa}$, the compressive strength plan $30 \mathrm{Mpa}$, amounting to $31.501 \mathrm{Mpa}$, the split tensile strength test with the compressive strength plan $23 \mathrm{Mpa}$ is 1.957 $\mathrm{Mpa}$ and the compressive strength plan $30 \mathrm{MPa}$ is $2.769 \mathrm{Mpa}$, the strength test flexural compressive strength plan $23 \mathrm{Mpa}$ is $3.022 \mathrm{Mpa}$, for compressive strength plan $30 \mathrm{Mpa}$ is $3.425 \mathrm{Mpa}$. The aggregate characteristics of the Battang river meet the Indonesian National Standard and can achieve the planned compressive strength value.
\end{abstract}

\section{Keywords: Battang River Aggregate, Compressive Strength Test, Split Tensile Test, Flexural Strength Test}

\section{PENDAHULUAN}

Di bidang konstruksi, beton merupakan salah satu bahan konstruksi saat ini banyak digunakan dalam pembangunan khususnya bidang infrastruktur. Semakin berkembangnya pengetahuan tentang teknologi beton, maka penggunaan material penyusun beton di arahkan untuk memanfaatkan bahan/material yang bersumber dari alam dan sumber dari pemanfaatan limbah.

Sungai battang memiliki agregat yang cukup bersih, dapat dilihat secara visual dengan aliran sungai cukup jernih membuat sungai Battang ini menjadi salah satu sumber agregat yang dimanfaatkan masyarakat setempat. Agergat sungai Battang sendiri sudah digunakan oleh beberapa masyarakat setempat sebagai bahan pembuatan beton dalam pembangunan konstruksi berskala kecil, namum belum dapat dipastikan sebagai bahan konstruksi yang memenuhi karakteristik seusai standar nasional Indonesia dan bahan konstruksi yang memiliki mutu beton yang baik untuk pembangunan konstruksi berskala sedang pada daerah setempat.

Terlihat dari bahan penyusun beton yaitu agregat kasar (kerikil), agregat halus (pasir), semen, air, dan bahan tambah (admixture). Agregat kasar (kerikil) dan agregat halus (pasir) merupakan penyusun 
beton yang paling banyak digunakan, sekitar $60 \%$ $70 \%$ dalam pencampuran sehingga material penyusun beton ini perlu diperbanyak lagi dengan memanfaatkan segala sumber alam yang ada di indonesia salah satunya adalah sungai-sungai yang terdapat banyak kandungan mineralnya atau agregat kasar (kerikil) dan agregat halus (pasir) pada sungai tersebut, salah satunya adalah sungai Battang.

Adapun tujuan dari penelitian ini adalah untuk mengetahui karakteristik agregat sungai battang yang akan digunakan sebagai bahan campuran beton dan mengetahui kekuatan beton dengan uji kuat tekan, kuat tarik belah dan kuat lentur dengan menggunakan agregat sungai Battang sebagai bahan campuran beton.

Beton terdiri dari $\pm 15 \%$ semen, $\pm 8 \%$ air, $\pm 3 \%$ udara, selebihnya pasir dan kerikil. Campuran tersebut setelah mengeras mempunyai sifat yang berbeda-beda, tergantung pada cara pembuatannya.

Menurut SNI 2847:2013, beton adalah campuran semen portland atau semen hidrolis lainnya, agregat halus, agregat kasar, dan air, dengan atau tanpa bahan tambahan (admixture). Seiring dengan penambahan umur, beton akan semakin mengeras dan akan mencapai kekuatan rencana ( $\left.f^{\prime} c\right)$ pada usia 28 hari. Beton memliki daya kuat tekan yang baik oleh karena itu beton banyak dipakai atau dipergunakan untuk pemilihan jenis struktur terutama struktur bangunan, jembatan dan jalan.

Adapun pengujian pada penelitian ini meliputi pengujian:

\section{Kuat Tekan Beton}

Kuat tekan dihitung dari beban tekan maksimum yang dapat ditahan dibagi dengan luas penampang benda uji.

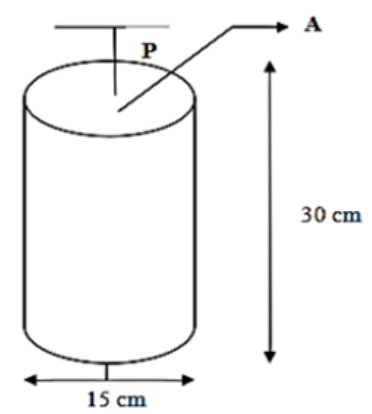

Gambar 1. Uji kuat tekan $\mathrm{f}^{\prime} \mathrm{c}=\frac{\mathrm{P}}{\mathrm{A}}$

\section{Kuat Lentur Beton}

Kuat lentur beton adalah kemampuan balok beton untuk menahan gaya dengan arah tegak lurus sumbu yang diberikan padanya sampai balok beton patah dan dinyatakan dalam Mega Pascal (MPa). Tegangan lentur ini dikenal dengan istilah Modulus Of Rupture.

Kuat lentur beton (Modulus Of Rupture) dihitung dengan menggunakan Persamaan dibawah, dengan mekanisme pengujian yang ditunjukkan pada Gambar 2.

$\mathrm{fr}=\frac{\mathrm{P} \times \mathrm{L}}{\mathrm{b} \times \mathrm{h}^{2}}$
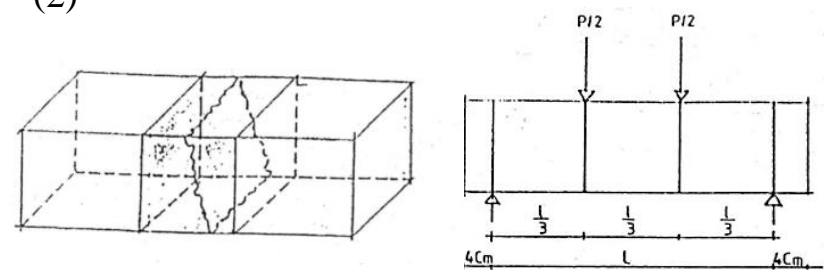

Gambar 2. Mekanisme pengujian kuat lentur dengan keruntuhan di tengah bentang

Persamaan digunakan bila terjadi keruntuhan ditengah bentang. Apabila keruntuhan terjadi pada bagian tarik di luar tengah bentang (Gambar 3), maka digunakan Persamaan.

$f r=\frac{3 \mathrm{Pxa}}{\mathrm{bx} \mathrm{h}^{2}}$
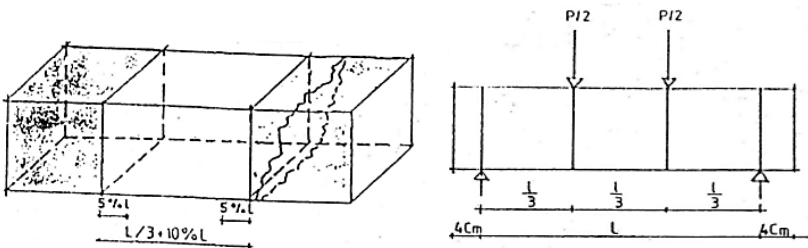

Gambar 3. Mekanisme pengujian lentur dengan keruntuhan di luar tengah bentang

3. Kuat Tarik Belah Beton

Kuat tarik belah adalah kuat tarik beton yang ditentukan berdasarkan kuat tekan belah dari silinder beton yang ditekan pada sisi panjangnya. Kekuatan tarik lebih sulit diukur dibandingkan dengan kekuatan tekan karena masalah penjepitan pada mesin

Pengujian tersebut menggunakan silinder beton berdiameter $150 \mathrm{~mm}$ dan panjang $300 \mathrm{~mm}$, diletakkan dengan arah memanjang di atas alat 
Paulus Civil Engineering Journal

E- Jurnal Teknik Sipil UKI-Paulus Makassar

http://ojs.ukipaulus.ac.id/index.php/pcej
Volume 2 No.4, Desember 2020

ISSN Online : $x x x x-x x x x$ penguji kemudian beban tekan diberikan merata ke arah tegak lurus dari atas pada seluruh panjang silinder. Apabila kuat tarik terlampaui, benda uji terbelah menjadi dua bagian dari ujung ke ujung. Tegangan tarik yang timbul sewaktu benda uji tarik belah disebut split cylinder strength atau kuat tarik belah.

Berdasarkan SNI 2491:2014 [1], nilai kuat tarik belah dapat dihitung dengan rumus:

$\mathrm{f}_{\mathrm{t}}=\frac{2 \mathrm{P}}{\pi \mathrm{LD}}$

(4)

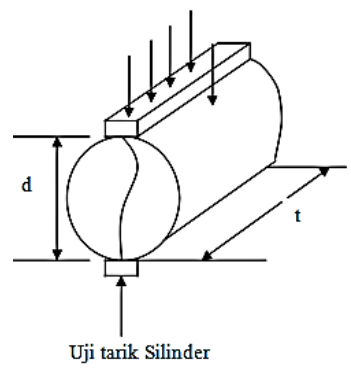

Gambar 4. Uji tarik belah

Pengujian kuat tarik belah beton dengan variasi kuat tekan beton, pengujian ini dengan menggunakan agregat halus yang berasaldari girian, agregat kasar berasal dari tateli. Hasil dari pengujian penelitian ini menyimpulkan bahwa agregat tersebut dapat mencapai kuat tekan beton normal [2]. Nilai kuat Tarik belah beton kertas pada penambahan serat nylon akan semakin besar dengan penambahan serat nylon [3]. Tinjauan kuat tekan,kuat tarik belah, dan kuat lentur beton menggunakan tras jatiyoso sebagai pengganti pasir untuk perkerasan kaku (Rigid pavement), yang dimana pengujian ini mengunakan agregat atau batuan gunung berapi. Dari pengujian yang dilakukan didapatkan nilai hasil kuat tekan sebesar 27,304 Mpa [4]. Kuat Tarik belah dan kuat lentur beton dengan penambahan Styrofoam (styrocon). Pada pengujian ini didapatkan nilai hasil pengujian kua tekan sebesar 18,08 Mpa [3]. Pada pengujian kuat tekan beton, hasil optimum yang didapat adalah benda uji KT-M0,03-G dengan komposisi bahan tambah madu sebesar $0,03 \%$ dan amylum sebesar $0,5 \%$ dari berat semen; Pada pengujian kuat tarik belah beton, didapat hasil optimum pada benda uji KTB-M0-A dengan komposisi madu 0\% dan amylum 0,10\% dari berat semen. [5]. Studi kekuatan tarik dan lentur beton dengan menggunaakan kaca sebagai filler dan pengganti agregat halus pada campuran beton. Penggunaan kaca sebagai bahan substitusi ternyata membuat kuat tekan beton menjadi menurun sehingga tidak direkomendasikan sebagai bahan campuran beton [6].Perbandingan kuat tekan dan kuat Tarik belah antara beton normal dan beton integral waterproofing menghasilkan adanya penurunan kuat tekan karakteristik pada beton integral terhadap beton normal sedangkan pada kuat Tarik belah terjadi peningkatan[7]. Pada umur mulai 7 hari, kuat tekan beton dapat mengimbangi tulangan hingga mencapai kondisi luluh dan mempercepat pembongkaran scaffolding [8]. Kuat tekan beton berbanding lurus terhadap kuat tekan lentur [9], penggunaan steelfiber pada campuran beton mutu f'c $25 \mathrm{MPa}$ mengalami kuat tekan sebesar 19,23\% dan kuat lentur sebesar 37,99\% [10].

\section{METODE}

Tempat pengambilan material yang akan di buat sebagai bahan penelitian berupa agregat kasar (kerikil) dan agrega halus (pasir) berada di Sungai Battang, Kota Palopo, Kecamatan Wara Barat, Kelurahan Lebang, pengambilan agregat kasar dan agregar halus pada tanggal 01-06 Juni 2020. Adapun tempat pengambilan material seperti gambar 5 .

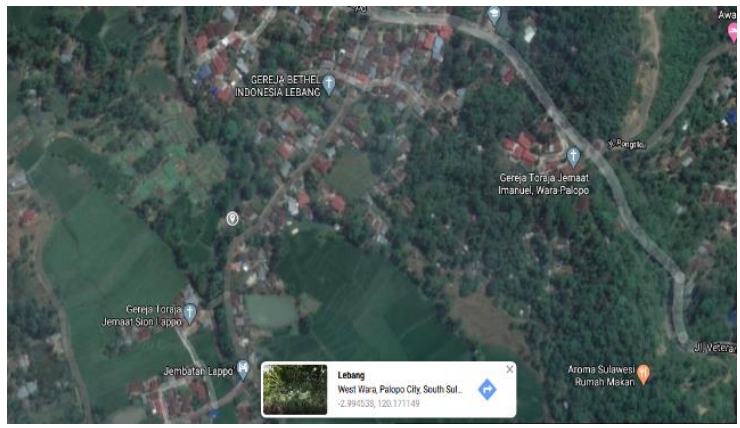

Gambar 5. Lokasi pengambilan material

Penelitian ini dilakukan di labolatorium struktur dan bahan, Jurusan Teknik Sipil, Fakultas Teknik, Universitas Kristen Indonesia Paulus, Makassar. Adapun jenis penelitian eksperimental di laboratorium berupa pengujian karakteristik material, pengujian kuat tekan, pengujian kuat tarik belah dan kuat lentur beton. Waktu penelitian yang direncanakan kurang lebih 3 bulan mulai bulan Juni - Agustus 2020.

Pengujian Keausan (Abration) dengan Mesin Los Angeles (SNI 2417:2008).Tujuan dari percobaan ini untuk menentukan tingkat keausan agregat dengan menggunakan mesin los angeles dengan perbandingan berat benda yang lolos saringan No.12 $(1,7)$ dengan berat semula, dalam \%. Penelitian ini menggunakan bahan dari: 1. Semen Portland Komposit (PCC) 
2. Agregat halus dari Sungai Battang, Kecamatan Wara Barat, Kota Palopo Sulawesi Selatan.

3. Agregat kasar dari Sungai Battang, Kecamatan Wara Barat, Kota Palopo Sulawesi Selatan.

4. Air sumur bor di Laboratorium Teknologi dan Bahan Beton Universitas Kristen Indonesia Paulus Makassar.

Dalam penelitian ini, agregat yang digunakan untuk campuran harus diperiksa karakteristik sebelum digunakan sebagai benda uji untuk menjamin kualitas mutunya. Pengujian karakteristik agregat dilakukan berdasarkan spesifikasi yang telah ditetapkan.

1. Pemeriksaan analisa saringan

2. Pemeriksaan berat jenis dan penyerapan

3. Pemeriksaan berat volume

4. Pemeriksaan kadar air

5. Pemeriksaan kadar lumpur

6. Pemeriksaan zat organic

Adapun hasil pemeriksaan karakteristik agregat kasar dan agregat halus berdasarkan SNI sebagai berikut:

Tabel 1. Hasil rekapitulasi pemeriksaan karakteristik agregat kasar

\begin{tabular}{ccccc}
\hline No. & Karakteristik & Hasil & Interval SNI & Keterangan \\
\hline 1 & Kadar Air & $0,766 \%$ & $0,50 \%-2,00 \%$ & Memenuhi \\
2 & Kadar Lumpur & $0,462 \%$ & $0,20 \%-1,00 \%$ & Memenuhi \\
3 & Berat Volume Padat & $1625,556 \mathrm{~kg} / \mathrm{m}^{3}$ & $1400-1900 \mathrm{~kg} / \mathrm{m}^{3}$ & Memenuhi \\
4 & Berat Volume Gembur & $1517,778 \mathrm{~kg} / \mathrm{m}^{3}$ & $1400-1900 \mathrm{~kg} / \mathrm{m}^{3}$ & Memenuhi \\
5 & Berat Jenis SSD & 2,757 & $1,60-3,20$ & Memenuhi \\
6 & Absorpsi (Penyerapan) & $1,75 \%$ & $0,20 \%-2,00 \%$ & Memenuhi \\
7 & Modulus Kehalusan & 2,999 & $5,50-8,00$ & Tidak Memenuhi \\
8 & Keausan & $18 \%$ & $<40 \%$ & Memenuhi \\
\hline
\end{tabular}

Tabel 2. Spesifikasi karakteristik agregat halus

\begin{tabular}{ccc}
\hline Karakteristik Agregat Halus & Interval Batas & Pedoman \\
\hline Kadar lumpur, \% & $0,2-6$ & SNI 03-4142:1996 \\
Kadar organik, warna & $>3$ & SNI 2816:2014 \\
Kadar air, \% & $3-5$ & SNI 03-1971:2011 \\
Berat volume padat, kg/ltr & $1,40-1,90$ & SNI 03-4804:1998 \\
Berat volume gembur, kg/ltr & $0,20-2,00$ & SNI 03-4804:1998 \\
Penyerapan,\% & $0,20-2,00$ & SNI 1970:2008 \\
Berat jenis (SSD) & $1,6-3,2$ & SNI 1970:2008 \\
Modulus kehalusan & $2,20-3,10$ & SNI-ASTM-C136-2012 \\
\hline
\end{tabular}

Hasil pemeriksaan analisa saringan agregat kasar dan agregat halus ini mengacu pada standar SNI 03-2834-2000 dimana masing-masing saringan memiliki syarat gradasi agregat baik agegat.

Tabel 3. Syarat gradasi agregat kasar

\begin{tabular}{cccc}
\hline \multirow{2}{*}{$\begin{array}{c}\text { Ukuran } \\
\text { Saringan } \\
(\mathrm{mm})\end{array}$} & \multicolumn{3}{c}{$\begin{array}{c}\text { Persentase Lolos (\%) } \\
\text { Gradasi Agregat }\end{array}$} \\
\cline { 2 - 4 } & $40 \mathrm{~mm}$ & $20 \mathrm{~mm}$ & $10 \mathrm{~mm}$ \\
\hline 76,2 & 100 & - & - \\
36,1 & 95100 & 100 & - \\
19,1 & $35-70$ & $95-100$ & 100 \\
9,52 & $10-40$ & $30-60$ & $50-85$ \\
4,75 & $0-5$ & $0-10$ & $0-10$ \\
\hline
\end{tabular}

Dengan mengacu pada syarat gradasi tersebut maka grafik yang diperoleh dari data hasil pemeriksaaan analisa saringa agregat kasar pada penelitian ini dapat dilihat 6 :

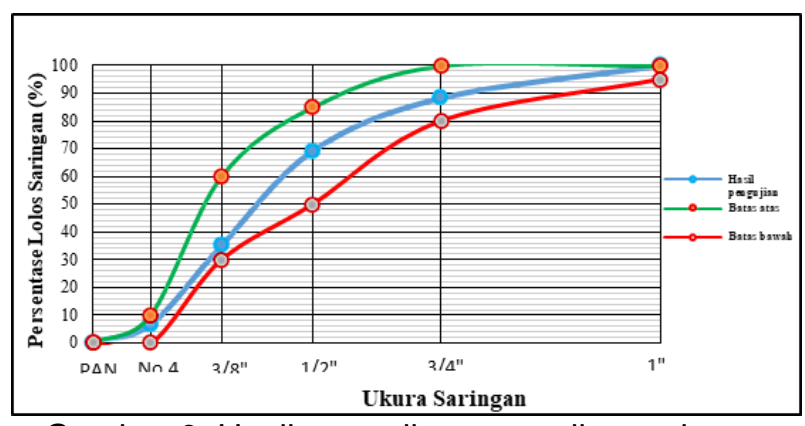

Gambar 6. Hasil pemeriksaan analisa saringan agregat kasar 
Grafik yang diperoleh dari hasil pemeriksaan analisa saringan pada penelitian ini dapat dilihat pada Gambar 7.

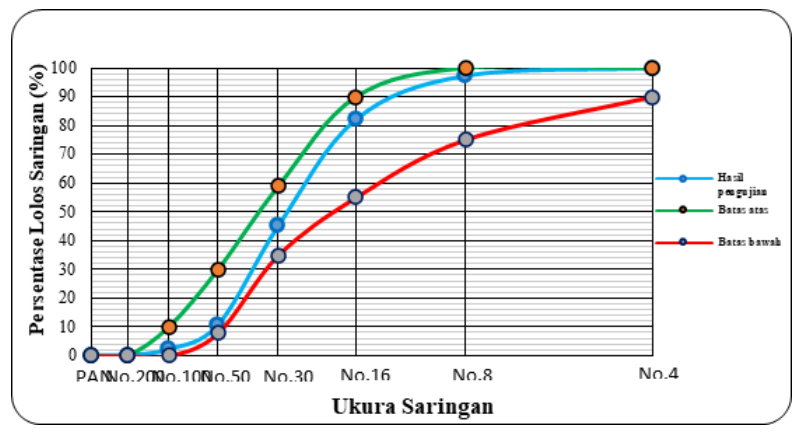

Gambar 7. Hasil pemeriksaan analisa saringan agregat halus

hasil pemeriksaan analisa saringan agregat sungai Battang ini terdapat pada gradasi Zona 2 (agak kasar). Dari hasil pemeriksaan material dan berdasarkan kuat tekan rencana beton ( $\left.f^{\prime} c\right)$ sebesar $23 \mathrm{Mpa}$ dan (f'c) sebesar $30 \mathrm{Mpa}$ maka dari hasil perhitungan Mix Design diperoleh komposisi agregat, air dan semen dilihat pada tabel 4 .

Tabel 4. Kuat tekan rencana

\begin{tabular}{ccccccc}
\hline $\begin{array}{c}\text { Kuat Tekan } \\
\text { Rencana }\left(\mathrm{f}^{\prime} \mathrm{c}\right)\end{array}$ & Rencana Pembuatan Beton & \multicolumn{3}{c}{ Kebutuhan Bahan Dasar Beton } \\
\hline $\mathrm{f}^{\prime} \mathrm{c}$ & Volume & $\begin{array}{c}\text { Berat } \\
(\mathrm{Kg})\end{array}$ & $\begin{array}{c}\text { Air } \\
(\mathrm{Liter})\end{array}$ & $\begin{array}{c}\text { Semen } \\
(\mathrm{kg})\end{array}$ & $\begin{array}{c}\text { Agregat } \\
\text { Halus } \\
(\mathrm{kg})\end{array}$ & $\begin{array}{c}\text { Agregat } \\
\text { Kasar } \\
(\mathrm{kg})\end{array}$ \\
23 & $1 \mathrm{~m}^{3}$ & 24,13 & 1,94 & 3,67 & 7,23 & 11,27 \\
30 & $1 \mathrm{~m}^{3}$ & 24,13 & 1,95 & 4,41 & 6,49 & 11,27 \\
\hline
\end{tabular}

Hasil perhitungan Mix Design didapatkan Perbandingan antara Semen, Agregat Halus dan Agregat Kasar yaitu:

1. Untuk f'c $23 \mathrm{Mpa}=1$ (Semen): 2 (Agregat Halus) : 3 (Agregat Kasar)

2. Untuk f'c $30 \mathrm{Mpa}=1$ (Semen): 1,25 (Agregat Halus) : 2,12 (Agregat Kasar)

Pembuatan trial mix dilakukan untuk mengetahui apakah komposisi yang telah dihitung memenuhi kuat tekan rencana $\left(f^{\prime} c\right)$, dengan menggunakan faktor 7 hari untuk pengujian. Jika kuat tekan rencana $(f ' c)$ telah terpenuhi maka bisa di lanjutkan ke pembuatan benda uji.

Desain Benda Uji yaitu jenis benda uji yang digunakan yaitu: Silinder ukuran $150 \mathrm{~mm}$ x $300 \mathrm{~mm}$ untuk pengujian kuat tekan dan kuat tarik belah. Kuat lentur menggunakan balok $600 \mathrm{~mm} \times 150 \mathrm{~mm}$ x $150 \mathrm{~mm}$. Kuat tekan rencana $\left(f^{\prime} c\right)$ yaitu $23 \mathrm{Mpa}$ dan $30 \mathrm{Mpa}$. Slump test yang digunakan adalah 75 - $100 \mathrm{~mm}$. Nilai faktor air semen yang ditentukan adalah sebesar 0,60 dan jumlah sampel sebanyak 21 sampel.

Benda uji yang telah dilepas dari cetakan, akan dilakukan curing atau perawatan beton yang bertujuan untuk menjaga agar beton tidak cepat kehilangan air dan sebagai tindakan menjaga kelembaban/suhu beton sehingga beton dapat mencapai kuat tekan yang diinginkan. Perawatan benda uji ini dilakukan berdasarkan SNI 2493:2011.
Perawatan benda uji dilakukan dengan tujuan untuk mencegah terjadinya retak pada permukaan beton akibat penguapan air yang terlalu cepat pada beton yang masih muda dan Memperbesar kemungkinan tercapainya kekuatan beton yang disyaratkan dengan cara menstabilkan hidrasi semen.

\section{HASIL DAN PEMBAHASAN}

Prosedur Pengujian Kuat Tekan Beton dilaksanakan berdasarkan SNI 1974:2011, dimana nilai kuat tekan beton didapatkan pada saat benda uji berumur 7 hari, 14 hari, 21 hari dan 28 hari di uji dengan menggunakan Compression Testing Machine untuk mendapatkan beban maksimum yaitu beban pada saat beton hancur ketika menerima beban tersebut $\left(P_{\text {maks }}\right)$ dalam satuan $\mathrm{KN}$.

\section{Kuat Tekan}

Setelah melalui uji tekan beton 7 hari, 14 hari, 21 hari dan 28 hari, maka dapat dilihat proses pengerasan beton berdasarkan kuat tekan rencana $\left(f^{\prime} c\right)=23$ dan $\left(f^{\prime} c\right)=30$ Mpa tiap sampel untuk setiap sampel parameter perendaman. Dari hasil pengujian seperti ditunjukkan pada gambar 8 . 
Tabel 5. Hasil kuat tekan rencana f'c (23 MPa)

\begin{tabular}{|c|c|c|c|c|c|c|c|c|}
\hline $\begin{array}{l}\text { Umur } \\
\text { (Hari) }\end{array}$ & $\begin{array}{c}\text { Berat } \\
\text { Beton } \\
(\mathrm{kg})\end{array}$ & $\begin{array}{l}\text { Luas } \\
\text { Silinder } \\
\left(\mathrm{mm}^{2}\right)\end{array}$ & $\begin{array}{c}\text { Beban } \\
\text { Maks } \\
(\mathrm{N})\end{array}$ & $\begin{array}{c}\text { Kuat } \\
\text { Tekan } \\
\text { Aktual } \\
\left(\mathrm{N} / \mathrm{mm}^{2}\right)\end{array}$ & $\begin{array}{c}\text { Kuat } \\
\text { Tekan } \\
\text { Aktual } \\
\text { Rata-rata } \\
(\mathrm{N} / \mathrm{mm})\end{array}$ & $\begin{array}{l}\text { Faktor } \\
\text { Umur }\end{array}$ & $\begin{array}{l}\text { Kuat } \\
\text { Tekan } \\
\text { Beton } \\
\text { (Mpa) }\end{array}$ & $\begin{array}{c}\text { Kuat } \\
\text { Tekan } \\
\text { Beton } \\
\text { rata-rata } \\
\text { (Mpa) }\end{array}$ \\
\hline 7 & $\begin{array}{l}12,55 \\
12,63 \\
11,52\end{array}$ & & $\begin{array}{l}270000 \\
260000 \\
265000\end{array}$ & $\begin{array}{l}15,279 \\
14,713 \\
14,996\end{array}$ & 14,996 & 0,65 & $\begin{array}{l}23,506 \\
22,635 \\
23,071\end{array}$ & 23,071 \\
\hline 14 & $\begin{array}{l}12,68 \\
12,67 \\
12,69\end{array}$ & & $\begin{array}{l}360000 \\
365000 \\
360000\end{array}$ & $\begin{array}{l}20,372 \\
20,655 \\
20,372\end{array}$ & 20,466 & 0,88 & $\begin{array}{l}23,150 \\
23,471 \\
23,150\end{array}$ & 23,257 \\
\hline 21 & $\begin{array}{l}12,76 \\
12,55 \\
12,42\end{array}$ & & $\begin{array}{l}405000 \\
395000 \\
388000\end{array}$ & $\begin{array}{l}22,918 \\
22,352 \\
21,956\end{array}$ & 22,409 & 0,95 & $\begin{array}{l}24,124 \\
23,529 \\
23,112\end{array}$ & 23,588 \\
\hline 28 & $\begin{array}{l}12,51 \\
12,49 \\
12,46\end{array}$ & & $\begin{array}{l}430000 \\
415000 \\
420000\end{array}$ & $\begin{array}{l}24,333 \\
23,484 \\
23,767\end{array}$ & 23,861 & 1 & $\begin{array}{l}24,333 \\
23,484 \\
23,767\end{array}$ & 23,861 \\
\hline
\end{tabular}

Tabel 6. Hasil kuat tekan rencana f'c (30 MPa)

\begin{tabular}{|c|c|c|c|c|c|c|c|c|}
\hline $\begin{array}{l}\text { Umur } \\
\text { (Hari) }\end{array}$ & $\begin{array}{c}\text { Berat } \\
\text { Beton } \\
(\mathrm{kg})\end{array}$ & $\begin{array}{l}\text { Luas } \\
\text { Silinder } \\
\left(\mathrm{mm}^{2}\right)\end{array}$ & $\begin{array}{c}\text { Beba } \\
n \\
\text { Maks } \\
(\mathrm{N})\end{array}$ & $\begin{array}{c}\text { Kuat Tekan } \\
\text { Aktual } \\
\left(\mathrm{N} / \mathrm{mm}^{2}\right)\end{array}$ & $\begin{array}{c}\text { Kuat } \\
\text { Tekan } \\
\text { Aktual } \\
\text { Rata-rata } \\
(\mathrm{N} / \mathrm{m})\end{array}$ & $\begin{array}{l}\text { Faktor } \\
\text { Umur }\end{array}$ & $\begin{array}{l}\text { Kuat } \\
\text { Tekan } \\
\text { Beton } \\
\text { (Mpa) }\end{array}$ & $\begin{array}{c}\text { Kuat } \\
\text { Tekan } \\
\text { Beton } \\
\text { rata-rata } \\
\text { (Mpa) }\end{array}$ \\
\hline 7 & $\begin{array}{l}12,61 \\
12,87 \\
12,81\end{array}$ & & $\begin{array}{l}3500 \\
3450 \\
3600\end{array}$ & $\begin{array}{l}19,806 \\
19,523 \\
20,372\end{array}$ & 19,900 & 0,65 & $\begin{array}{l}30,471 \\
29,600 \\
30,906\end{array}$ & 30,326 \\
\hline 14 & $\begin{array}{l}12,82 \\
12,78 \\
12,72\end{array}$ & & $\begin{array}{l}4600 \\
4700 \\
4700\end{array}$ & $\begin{array}{l}26,031 \\
26,596 \\
26,596\end{array}$ & 26,408 & 0,88 & $\begin{array}{l}30,223 \\
30,545 \\
30,545\end{array}$ & 30,438 \\
\hline 21 & $\begin{array}{l}12,82 \\
12,82 \\
12,82\end{array}$ & 17 & $\begin{array}{l}5000 \\
5200 \\
5150\end{array}$ & $\begin{array}{l}28,294 \\
29,426 \\
29,143\end{array}$ & 28,954 & 0,95 & $\begin{array}{l}29,783 \\
30,975 \\
30,677\end{array}$ & 30,478 \\
\hline 28 & $\begin{array}{l}12,66 \\
12,66 \\
12,66\end{array}$ & & $\begin{array}{l}5600 \\
5500 \\
5600\end{array}$ & $\begin{array}{l}31,689 \\
31,124 \\
31,689\end{array}$ & 31,501 & 1 & $\begin{array}{l}31,689 \\
31,124 \\
31,689\end{array}$ & 31,501 \\
\hline
\end{tabular}




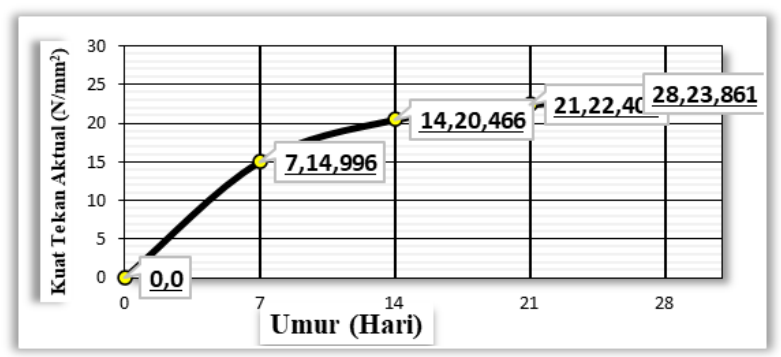

Gambar 8. Grafik beban Maks (f'c $23 \mathrm{Mpa}$ ) terhadap umur beton

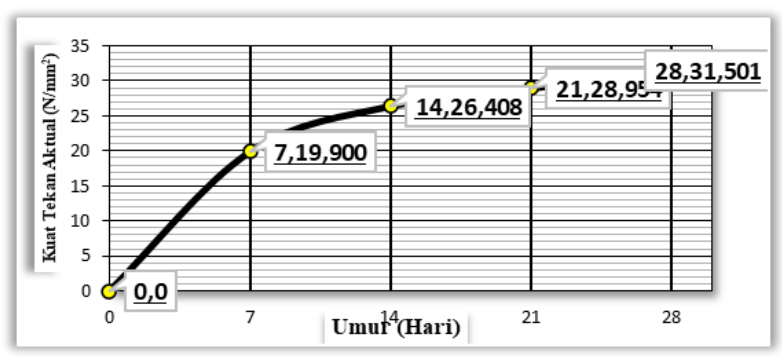

Gambar 9. Grafik beban Maks (f'c $30 \mathrm{Mpa}$ ) terhadap umur beton

\section{Kuat Tarik Belah}

Pengujian kuat tarik belah beton dilaksakan berdasarkan SNI 2491:2014, pada saat benda uji 28 hari dengan menggunakan Compression Testing Machine untuk mendapatkan beban maksimum yaitu pada saat benda uji hancur ketika menerima beban tersebut $\left(P_{\text {maks }}\right)$ dalam satuan $\mathrm{KN}$.

Tabel 7. Hasil uji kuat tarik belah (f'c $23 \mathrm{Mpa}$ )

\begin{tabular}{cccc}
\hline $\begin{array}{c}\text { Umur } \\
\text { (Hari) }\end{array}$ & $\begin{array}{c}\text { Beban } \\
\text { Maks } \\
(\mathrm{KN})\end{array}$ & $\begin{array}{c}\text { Kuat Tarik } \\
\text { Belah }\left(f_{t}\right) \\
\left(\mathrm{N} / \mathrm{mm}^{2}\right)\end{array}$ & $\begin{array}{c}\text { Kuat Tarik } \\
\text { Belah }\left(f_{t}\right)\end{array}$ \\
$\begin{array}{c}\text { Rata-rata } \\
(\mathrm{Mpa})\end{array}$ \\
28 & 135 & 1,910 & \\
& 140 & 1,981 & 1,957 \\
& 140 & 1,981 & \\
\hline
\end{tabular}

Tabel 8. Hasil uji kuat tarik belah (f'c $30 \mathrm{Mpa}$ )

\begin{tabular}{cccc}
\hline $\begin{array}{c}\text { Umur } \\
\text { (Hari) }\end{array}$ & $\begin{array}{c}\text { Beban } \\
\text { Maks } \\
(\mathrm{KN})\end{array}$ & $\begin{array}{c}\text { Kuat Tarik } \\
\text { Belah }\left(f_{t}\right) \\
\left(\mathrm{N} / \mathrm{mm}^{2}\right)\end{array}$ & $\begin{array}{c}\text { Kuat Tarik } \\
\text { Belah }\left(f_{t}\right) \\
\text { Rata-rata } \\
(\mathrm{Mpa})\end{array}$ \\
\hline \multirow{2}{*}{28} & 190 & 2,688 & \\
& 195 & 2,759 & 2,759 \\
& 200 & 2,829 & \\
\hline
\end{tabular}

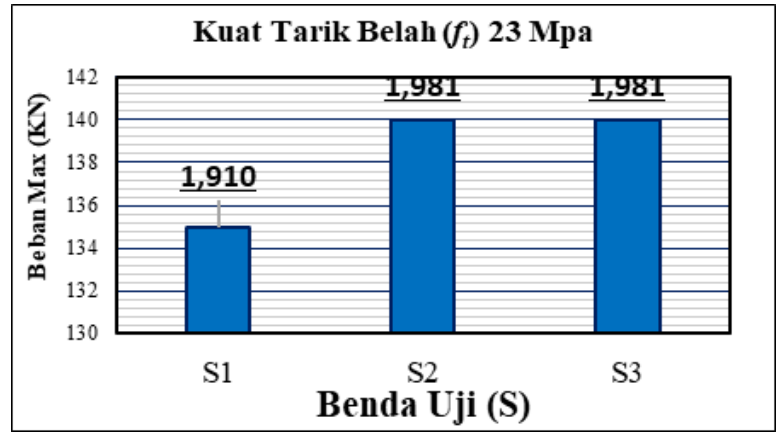

Gambar 10. Grafik hubungan kuat tarik belah terhadap benda uji

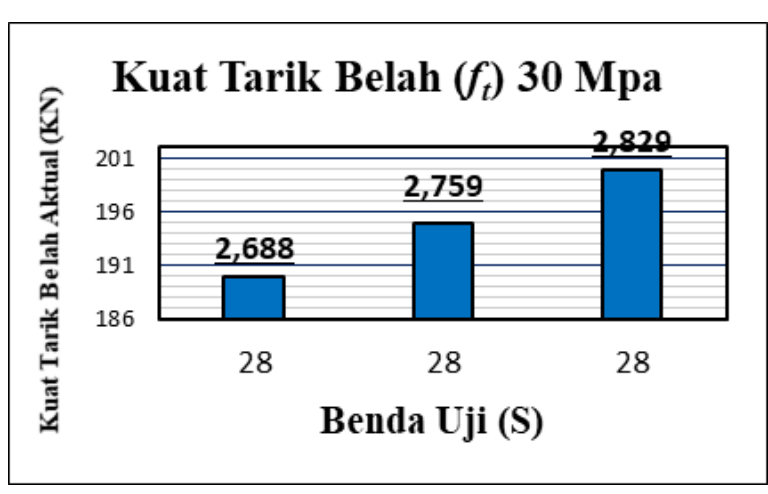

Gambar 11. Grafik hubungan kuat tarik belah aktual terhadap benda uji

\section{Kuat Lentur}

Prosedur pengujian kuat lentur dilaksanakan berdasarkan SNI 4431-2011, dengan benda uji berbentuk balok dengan ukuran $60 \times 15 \times 15 \mathrm{~cm}$. Benda uji diletakkan pada alat uji lentur dengan dua titik pembebanan.

Tabel 9. Hasil uji kuat lentur $\left(f_{r}\right) 23 \mathrm{Mpa}$

\begin{tabular}{ccccc}
\hline $\begin{array}{c}\text { Umu } \\
r\end{array}$ & $\begin{array}{c}\text { Beban } \\
\text { Maks } \\
\text { (ton) }\end{array}$ & $\begin{array}{c}\text { Beban } \\
\text { Maks } \\
(\mathrm{N})\end{array}$ & $\begin{array}{c}\text { Kuat } \\
\text { Lentur } f_{r} \\
\left(\mathrm{~N} / \mathrm{mm}^{2}\right)\end{array}$ & $\begin{array}{c}\text { Kuat } \\
\text { Lentur } f_{r} \\
\text { Rata-rata } \\
(\mathrm{Mpa})\end{array}$ \\
\hline 28 & 1,9 & 1,863 & 2,871 & \\
28 & 2 & 1,961 & 3,022 & 3,022 \\
28 & 2,1 & 2,056 & 3,173 & \\
\hline
\end{tabular}

Tabel 10. Hasil uji kuat lentur $\left(f_{r}\right) 30 \mathrm{Mpa}$

\begin{tabular}{ccccc}
\hline Umur & $\begin{array}{c}\text { Beban } \\
\text { Maks } \\
\text { (ton) }\end{array}$ & $\begin{array}{c}\text { Beban } \\
\text { Maks } \\
(\mathrm{N})\end{array}$ & $\begin{array}{c}\text { Kuat } \\
\text { Lentur } \\
f_{r} \text { (Mpa) }\end{array}$ & $\begin{array}{c}\text { Kuat } \\
\text { Lentur } f_{r} \\
\text { Rata- } \\
\text { rata } \\
\text { (Mpa) }\end{array}$ \\
\hline 28 & 2,2 & 2,157 & 3,324 & \\
28 & 2,3 & 2,256 & 3,475 & 3,425 \\
28 & 2,3 & 2,256 & 3,475 & \\
\hline
\end{tabular}




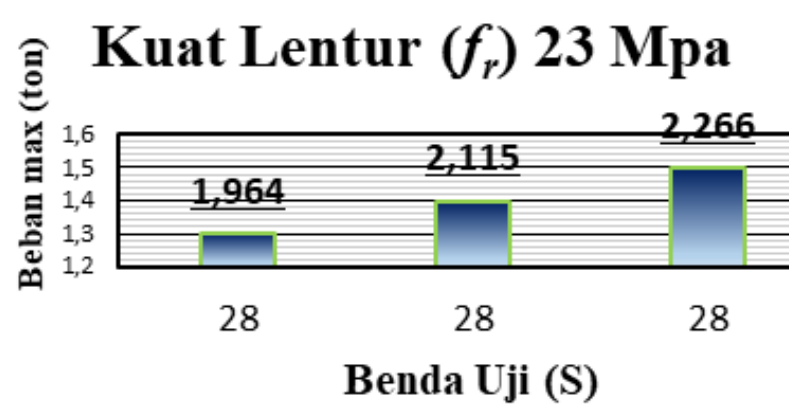

Gambar 12. Grafik hubungan kuat lentur terhadap benda uji

Dalam penetilian yang dilakukan, diperoleh nilai kuat tekan beton rencana $\left(f^{\prime} c\right) 23$ sebesar 23,861 Mpa dan kuat tekan rencana ( $\left.f^{\prime} c\right) 30$ sebesar 31,501 Mpa, sedangkan untuk kuat tarik belah

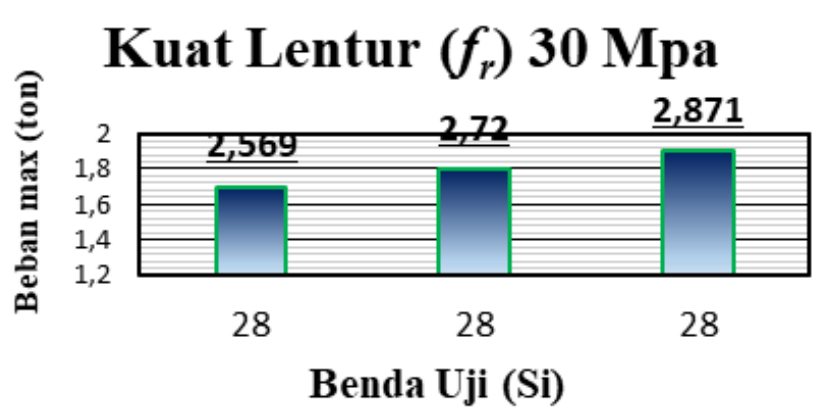

Gambar 13. Grafik hubungan kuat lentur terhadap benda uji

rencana $\left(f_{t}\right) 23$ sebesar 1,957 Mpa dan untuk kuat tarik belah rencana $\left(f_{t}\right) 30$ sebesar 2,759 Mpa. Sehingga dapat dihitung persentase kuat tarik belah terhadap kuat tekan beton:

Tabel 11. Persentase Kuat Tarik Belah Terhadap Kuat Tekan ( $\left.f^{\prime} c\right) 23$ Mpa

\begin{tabular}{|c|c|c|c|c|c|c|}
\hline Pengujian & $\begin{array}{l}\text { Nomor } \\
\text { Sampel }\end{array}$ & Umur & $\begin{array}{c}\text { Gaya } \\
\text { Tekan } \\
\text { (N) }\end{array}$ & $\begin{array}{l}\text { Tegangan } \\
\text { Maks (Mpa) }\end{array}$ & $\begin{array}{c}\text { Rumus } \\
\text { Persentase }\end{array}$ & $\begin{array}{c}\text { Persentase } \\
\text { Kuat Tarik } \\
\text { belah } \\
(\%)\end{array}$ \\
\hline \multirow{2}{*}{$\begin{array}{l}\text { Kuat Tekan } \\
\quad\left(f^{\prime} c\right)\end{array}$} & $\begin{array}{l}\text { D28 } \\
\text { D29 }\end{array}$ & \multirow{3}{*}{28} & $\begin{array}{l}560 \\
550\end{array}$ & $\begin{array}{l}31,689 \\
31,124\end{array}$ & $\frac{\mathrm{S} 1}{\mathrm{D} 28} \times 100 \%$ & 8,482 \\
\hline & $\begin{array}{l}\text { D30 } \\
\text { S1 }\end{array}$ & & $\begin{array}{l}560 \\
190\end{array}$ & $\begin{array}{c}31,689 \\
2,688\end{array}$ & $\frac{\mathrm{S} 2}{\mathrm{D} 29} \times 100 \%$ & 8,864 \\
\hline $\begin{array}{l}\text { Kuat Tarik } \\
\text { Belah (ft) }\end{array}$ & $\begin{array}{l}\text { S2 } \\
\text { S3 }\end{array}$ & & $\begin{array}{l}195 \\
200 \\
\end{array}$ & $\begin{array}{l}2,759 \\
2,829 \\
\end{array}$ & $\frac{\mathrm{S} 3}{\mathrm{D} 30} \times 100 \%$ & 8,929 \\
\hline
\end{tabular}

Tabel 12. Persentase kuat tarik belah terhadap kuat tekan (f'c) $30 \mathrm{Mpa}$

\begin{tabular}{|c|c|c|c|c|c|c|}
\hline Pengujian & $\begin{array}{l}\text { Nomor } \\
\text { Sampel }\end{array}$ & Umur & $\begin{array}{l}\text { Gaya } \\
\text { Tekan } \\
\text { (N) }\end{array}$ & $\begin{array}{c}\text { Tegangan } \\
\text { Maks } \\
\text { (Mpa) }\end{array}$ & $\begin{array}{c}\text { Rumus } \\
\text { Persentase }\end{array}$ & $\begin{array}{c}\text { Persentase } \\
\text { Kuat Tarik } \\
\text { belah } \\
(\%)\end{array}$ \\
\hline $\begin{array}{l}\text { Kuat } \\
\text { Tekan }\end{array}$ & $\begin{array}{l}\text { D7 } \\
\text { D8 }\end{array}$ & \multirow{3}{*}{28} & $\begin{array}{l}430 \\
415\end{array}$ & $\begin{array}{l}24,333 \\
23,484\end{array}$ & $\frac{\mathrm{S} 1}{\mathrm{D} 7} \times 100 \%$ & 7,849 \\
\hline $\begin{array}{c}\left(f^{\prime} \mathrm{c}\right) \\
\text { Kuat Tarik }\end{array}$ & $\begin{array}{l}\text { D9 } \\
\text { S1 }\end{array}$ & & $\begin{array}{l}420 \\
135\end{array}$ & $\begin{array}{c}23,767 \\
1,910\end{array}$ & $\frac{S 2}{D 8} \times 100 \%$ & 8,434 \\
\hline $\begin{array}{c}\text { Belah } \\
\text { (ft) }\end{array}$ & S2 & & 140 & 1,981 & $\frac{\mathrm{S} 3}{\mathrm{D} 9} \times 100 \%$ & 8,333 \\
\hline
\end{tabular}


Paulus Civil Engineering Journal

E- Jurnal Teknik Sipil UKI-Paulus Makassar http://ojs.ukipaulus.ac.id/index.php/pcej

Dalam penelitian diperoleh nilai kuat lentur beton pada umur 28 adalah 3,022 Mpa untuk kuat lentur rencana $23 \mathrm{Mpa}$ dan 3,425 Mpa untuk kuat lentur rencana $30 \mathrm{Mpa}$. Sedangkan nilai kuat tekan pada umur 28 hari adalah 23,861 Mpa untuk kuat tekan rencana $23 \mathrm{Mpa}$ dan 31,501Mpa untuk kuat tekan rencana 30Mpa. SNI 2847:2013 Pasal 9.5.2.3 memberikan korelasi antara modulus keruntuhan beton dengan kuat tekan, yaitu :

$f_{r}=0,62 \lambda \sqrt{f^{\prime} c}(\lambda=1,0$ pada beton Normal $)$

$f_{r}=x \sqrt{f^{\prime} c}$

$\mathrm{X}=\frac{f r}{\sqrt{f^{\prime} c}}$

dengan $\lambda$ adalah faktor untuk beton ringan.

Tabel 13. Koefisien kuat lentur terhadap kuat tekan (f'c) $23 \mathrm{Mpa}$

\begin{tabular}{cccc}
\hline Pengujian & Umur & $\begin{array}{c}\text { Tegangan } \\
\text { Maks Rata- } \\
\text { rata (Mpa) }\end{array}$ & $\begin{array}{c}\text { Koefisien } \\
(\mathrm{X})\end{array}$ \\
\hline Kuat Tekan (f'c) & 28 & 23,861 & 0,62 \\
$\begin{array}{c}\text { Kuat Tarik Belah } \\
(\mathrm{ft})\end{array}$ & 3,022 & \\
\hline
\end{tabular}

Tabel 14. Koefisien kuat lentur terhadap kuat tekan (f'c) $30 \mathrm{Mpa}$

\begin{tabular}{cccc}
\hline Pengujian & Umur & $\begin{array}{c}\text { Tegangan } \\
\text { Maks Rata- } \\
\text { rata } \\
(\mathrm{Mpa})\end{array}$ & $\begin{array}{c}\text { Koefisien } \\
(\mathrm{X})\end{array}$ \\
\hline Kuat Tekan (f'c) & 28 & 31,501 & 0,62 \\
$\begin{array}{c}\text { Kuat Tarik } \\
\text { Belah (ft) }\end{array}$ & & 3,425 & \\
\hline
\end{tabular}

\section{KESIMPULAN}

Agregat sungai battang dapat digunakan sebagai bahan campuran karena karakteristik agregat sungai Battang memenuhi Standar Nasional Indonesia.

Dari hasil penelitian, agregat sungai Battang sebagai bahan campuran beton ini mampu mencapai nilai kuat tekan yang direncanakan.
Volume 2 No.4, Desember 2020

ISSN Online : $x x x x-x x x x$

\section{DAFTAR PUSTAKA}

[1] F. P. Pane, H. Tanudjaja, and R. S. Windah, 2015, "Pengujian Kuat Tarik Lentur Beton Dengan Variasi Kuat Tekan Beton" J. Sipil Statik, Vol. 3, No.5

[2] E. Pratama dan E. S. Hisyam, 2016, "Kajian Kuat Tekan dan Kuat Tarik Belah Beton Kertas Dengan Bahan Tambah Serat Nylon", J. Fropil. Vol.4, No.1

[3] I. B. D. Giri and I. K. Sudarsana, 2008, "Kuat Tarik Belah dan Lentur Beton Dengan Penambahan Stryfoam" J.IImiah Teknik Sipil, Vol.12, no. 2

[4] A. U. Zhafira, E. Purwanto, and L. Irianti, 2017, "Studi Eksperimental Pengujian Kuat Tekan, Kuat Tarik Belah dan Kuat Lentur pada Campuran Beton dengan Penambahan Serat Kawat Bendrat Berkait," J. Rekayasa Sipil dan Desain, Vol.5, No.4

[5] F. S. Nugroho dan P. B. Rizalditya, 2017, "Kuat Tekan dan Kuat Tarik Belah Beton Polimer Termodifikasi Alami Amylum Serta Bahan Tambah Madu" G-SMART Vol.1, No.2

[6] I.M. Jaya, et al, 2017, "Perbandingan Kuat Tekan dan Kuat Tarik Belah Antara Beton Normal dan Beton Integral Waterproofing" J. Logic, Vol.17, No.3

[7] A. Ginting, 2019, "Perbandingan Peningkatan Kuat Tekan dengan Kuat Lentur pada Berbagai Umur Beton", J. Teknik Sipil, vol.7, no.2, 10.28932/jts.v7i2.1345

[8] T. Handayani,2019, "Memprediksi Kuat Lentur Berdasarkan Kuat Tekan Beton Normal", J. IImiah Desain dan Konstruksi, vol.18, no.2, http://dx.doi.org/10.35760/dk.2019.v18i2.2699

[9] Sukiesmo, D, Goetomo, dan G. S. Budi, 2016, "Studi Eksperimental Pengaruh Penggunaan Stell Fiber Terhadap Uji Kuat Tekan, Tarik Belah, dan Kuat Lentur Pada Campuran Beton Mutu f'c 25 MPa", JeLAST : Jurnal PWK, Laut, Sipil, Tambang, vol.1, no.1, http://dx.doi.org/10.26418/jelast.v1i1.145 06

[10] Standar Nasional Indonesia, 2014, Metode Uji Kekuatan Tarik Belah Spesimen Beton Silinder, Badan Standardisasi Nasional. 